\title{
PENGARUH RESIKO KREDIT, KECUKUPAN MODAL, HUTANG, DAN PENDAPATAN BUNGA TERHADAP PROFITABILITAS PADA PERUSAHAAN PERBANKAN YANG TERDAFTAR DI BURSA EFEK INDONESIA
}

\author{
SABETH SEMBIRING \\ Fakultas Ekonomi Program Studi Akuntansi Universitas Katolik Santo Thomas \\ sabethsembiring@gmail.com
}

\begin{abstract}
ABSTRAK
Adanya ketidaksesuaian antara teori dengan data yang diperoleh maka dilakukan penelitian yang bertujuan untuk menguji pengaruh resiko kredit yang dukur dengan non-performing loan, tingkat kecukupan modal yang diukur dengan capital adecuacy ratio, hutang yang diukur dengan debt equity ratio, dan pendapatan diukur dengan net interest margin terhadap profitabilitas yang diukur dengan return on assets pada perusahaan perbankan yang terdaftar di Bursa Efek Indonesia.Penelitian ini tergolong penelitian kausatif. Populasi dalam penelitian ini adalah seluruh perusahaan perbankan yang terdaftar di BEI tahun 2011 sampai 2015. Sedangkan sampel penelitian ini ditentukan dengan metode purposive sampling sehingga diperoleh 24 perusahaan sampel. Jenis data yang digunakan adalah data sekunder yang diperoleh dari www.idx.co.id. Metode analisis yang digunakan adalah analisis regresi berganda dengan tingkat signifikansi5 \%.Hasil uji secara parsial menunjukkan bahwa resiko kredit dan hutang berpengaruh negative dan signifikan terhadap profitabilitas, kecukupan modal tidak berpengaruh terhadap profitabilitas, pendapatan bunga berpengaruh positif dan signifikan terhadap profitabilitas. Hasil uji secara simultan menunjukkan rediko kredit, kecukupan modal, hutang, dan pendapatan bunga berpengaruh terhadap profitabilitas. Oleh karena itu perbankan memperhitungkan factor-faktor resiko kredit, kecukupan modal, hutang dan pendapatan bunga dalam konteks pencapaian tingkat laba yang diharapkan dengan memperhatikan kualitas penyaluran kredit, mengolah modal dengan baik dan menggunakan modal secara efektif, hutang yang dijadikan aktiva produktif diolah dengan baik, serta menjaga tingkat suku bunga kredit yang ditawarkan sehingga dapat menghasilkan modal yang tinggi.
\end{abstract}

Kata Kunci: Resiko Kredit, Tingkat Kecukupan Modal, Hutang, Pendapatan Bunga, Profitabilitas

\section{PENDAHULUAN}

Perkembangan pasar modal sebagai lembaga piranti investasi memiliki fungsi ekonomi dan keuangan yang semakin diperlukan oleh masyarakat sebagai media alternatif investasi dan penghimpun dana. Tujuan investor menginvestasikan dananya dalam bentuk instrumen investasi adalah untuk mendapatkan return yang maksimal. Oleh karena itu, investor harus memiliki berbagai pertimbangan-pertimbangan sebelum menginvestasikan dananya. Salah satunya adalah dengan mempertimbangkan kinerja perusahaan yang diukur melalui profitabilitas yaitu kemampuan perusahaan untuk menghasilkan laba.

Di era globalisasi sekarang ini tuntutan akan peningkatan taraf hidup setiap orang semakin tinggi. Hal ini mendorong setiap orang untuk meningkatkan taraf hidupnya dengan melakukan kegiatan membuka suatu usaha, melakukan investasi, dan kegiatan lainnya untuk mendapatkan penghasilan. Namun modal besar dalam menjalankan kegiatan untuk mendapatkan penghasilan selalu menjadi masalah utama dan terkadang menyebabkan usaha yang memerlukan modal tersebut menjadi terhambat. Untuk mengatasi masalah seperti ini 
maka bank menjadi salah satu pilihan untuk membiayai usaha tersebut melalui jasa kredit yang ditawarkan bank.

Menurut Kasmir (2008: 25), mengatakan bahwa pengertian bank adalah " Suatu Lembaga keuangan yang kegiatan utamanya adalah menerima simpanan giro, tabungan, dan deposito. Kemudian bank juga dikenal sebagai tempat untuk meminjam uang (kredit), selain itu bank juga dikenal sebagai tempat untuk menukar uang, memindahkan uang atau menerima segala macam bentuk pembayaran dan setoran seperti pembayaran listrik, air, pajak, uang kuliah, dan pembayaran lainnya. Sedangkan, menurut UU RI No. 10 tahun 1998 tentang Perbankan, yang dimaksud dengan bank adalah "Bank merupakan badan usaha yang menghimpun dana dari masyarakat dalam bentuk simpanan dan menyalurkannya kepada masyarakat dalam bentuk kredit dan atau bentuk lainnya dalam rangka meningkatkan taraf hidup rakyat". Dari uraian di atas dapat dijelaskan bahwa bank merupakan perusahaan yang bergerak dibidang keuangan, yang artinya usaha perbankan selalu berkaitan dengan masalah bidang keuangan. Jadi dapat diuraikan bahwa usaha perbankan meliputi tiga kegiatan utama yaitu: 1) Menghimpun dana 2) Menyalurkan dana 3) Memberikan jasa bank lainya.

Kepercayaan masyarakat dalam menyimpan dana di bank sangat dipengaruhi oleh informasi yang diperolehnya mengenai kualitas dan kinerja bank yang bersangkutan dengan salah satu indikatornya adalah menilai tingkat kesehatan bank. Bank yang sehat adalah bank yang dapat menjalankan fungsinya dengan baik, yang dapat menjaga dan memelihara kepercayaan masyarakat, menjalankan fungsinya, dapat membantu kelancaran lalu lintas pembayaran serta dapat dipergunakan oleh pemerintah dalam melaksanakan berbagai kebijakan, terutama kebijakan moneter. Apabila kondisi bank dalam keadaan sehat, maka perlu dipertahankan kesehatannya, akan tetapi jika kondisinya dalam keadaan tidak sehat maka perlu diambil tindakan untuk memperbaikinya. Dari penilaian tingkat kesehatan bank ini pada akhirnya akan menunjukkan bagaimana kinerja bank tersebut.

Salah satu yang dapat digunakan dalam mengukur kinerja suatu bank adalah melalui laporan keuangan yaitu dengan melihat profitabilitas bank tersebut. Dalam melakukan kegiatan operasionalnya, bank memiliki tujuan utama yaitu mencapai tingkat profitabilitas yang maksimal. Tingkat Profitabilitas dipengaruhi beberapa faktor yaitu resiko kredit, kecukupan modal, Hutang, dan Pendapatan Bunga.

Menurut Pandia (2012: 204) Resiko Kredit didefinisikan sebagai resiko kerugian sehubungan dengan pihak peminjam yang tidak dapat dan atau tidak mau memenuhi kewajiban untuk membayar kembali dana yang dipinjamkannya secara penuh pada saat jatuh tempo atau sesudahnya. Menurut Putri (2013) Resiko kredit yang dapat dikatakan sebagai kredit bermasalah (Non Performing Loan) dapat diartikan sebagai pinjaman yang mengalami kesulitan pelunasan akibat adanya faktor kesenjangan dan karena faktor eksternal di luar kemampuan kendali debitur. Resiko kredit diartikan juga yaitu resiko akibat kegagalan debitur dan/atau pihak lain dalam memenuhi liabilitas kepada Bank. Di industri perbankan, resiko kredit dapat timbul dari berbagai aktivitas fungsional perbankan seperti aktivitas perkreditan, aktivitas tresuri, serta trade finance. Dari aktivitas perkreditan, resiko kredit timbul akibat ketidakmampuan nasabah dalam membayar kewajiban dalam jangka waktu yang telah ditentukan dalam perjanjian pemberian kredit oleh pihak Bank kepada nasabah. Seperti pembayaran pokok pinjaman, pembayaran bunga dan lain lain yang tidak sesuai dengan jangka waktu yang telah ditetapkan dan apabila tidak dikelola dengan baik maka akan mengakibatkan kredit bermasalah (non performing loan) yang semakin besar sehingga akan berdampak pada kondisi perbankan yang akhirnya dapat mempengaruhi profitabilitas menurun pada bank tersebut.

Menurut Pandia (2012: 31) Modal merupakan faktor yang penting bagi bank dalam rangka pengembangan usaha dan menampung resiko kerugiannya. Menurut Novianty (2016: 26) Kecukupan modal adalah kemampuan bank dalam menanggung resiko kerugian yang 
mungkin timbul. Apabila modal yang dimiliki bank besar, maka kemampuan bank dalam menyalurkan pinjaman atau kredit juga besar sehingga kemampuannya untuk menciptakan laba juga bertambah.

Permodalan yang cukup untuk suatu perusahaan perbankan sangat penting karena dapat memberikan kepercayaan terhadap aktiva perbankan dalam menjalankan fungsinya yang diterima dari nasabah. Modal bank adalah dana yang diinvestasikan oleh pemilik dalam rangka pendirian badan usaha yang dimaksud untuk membiayai kegiatan usaha bank, permodalan ini di ukur dengan menggunakan Capital Adequacy Ratio yang merupakan rasio kecukupan modal.

Menurut Pandia (2012:181) Hutang pada bank identik dengan sumber dana bank itu sendiri, karena sebagian besar sumber dana bank berasal dari hutang (liabilities) bank terhadap nasabahnya dan merupakan kewajiban yang harus dipenuhi bilamana dana tersebut ditarik atau jatuh tempo. Menurut Rudianto (2008) dalam Irawan (2012) Hutang adalah kewajiban untuk menyerahkan uang, barang, atau jasa kepada pihak lain dimasa yang akan datang sebagai akibat dari transaksi yang telah terjadi dimasa yang lalu atau sebelumnya. Ditinjau dari jangka waktu pelunasan atau alat pelunasan hutang dapat di bagi menjadi dua kelompok yaitu hutang jangka pendek (hutang lancar) dan hutang jangka panjang. Pandia (2012: 182) semakin besar dana yang dapat dihimpun oleh suatu bank maka semakin besar kemampuan bank dalam menyalurkan kredit, ini berarti semakin besar jumlah pendapatan suatu bank. Hartono (2000:254) dalam Irawan (2012), menyebutkan juga bahwa hutang itu mengandung resiko. Semakin tinggi resiko perusahaan, semakin tinggi tingkat profitabilitas yang diharapkan sebagai imbalan terhadap tingginya resiko dan sebaliknya. Semakin rendah resiko perusahaan, semakin rendah tingkat profitabilitas yang diharapkan sebagai imbalan rendahnya resiko. Hutang ini di ukur dengan menggunakan Debt To Equity Rasio (DER) yang merupakan rasio hutang, ketentuan hutang yang merupakan perbandingan total hutang dengan total equity.

Menurut Kasmir (2008:131) Pendapatan Bunga (Bunga Pinjaman) adalah bunga yang diberikan kepada para peminjam atau harga yang harus dibayar nasabah peminjam kepada bank. Rasio yang digunakan untuk mengukur pendapatan bunga adalah Net Interest Margin (NIM). Net Interest Margin (NIM) adalah rasio antara aktiva produktif terhadap pendapatan bunga. Suatu bank dikatakan sehat apabila memiliki NIM diatas $2 \%$. Semakin besar rasio ini maka pendapatan bunga atas aktiva produktif yang dikelolah bank pun akan meningkat sehingga kemungkinan bank dalam kondisi bermasalah semakin kecil dan profitabilitas semakin meningkat.

Riyanto (1998:36) dalam Novianty (2016) Profitabilitas adalah kemampuan suatu bank dalam menghasilkan laba usaha dengan modal sendiri dan modal asing yang digunakan untuk menghasilkan laba tersebut.Salah satu yang dapat digunakan dalam mengukur kinerja suatu bank adalah melalui laporan keuangan yaitu dengan melihat profitabilitas bank tersebut. Dalam melakukan kegiatan operasionalnya, bank memiliki tujuan utama yaitu mencapai tingkat profitabilitas yang maksimal. Profitabilitas merupakan kemampuan bank untuk menghasilkan atau memperoleh laba secara efektif dan efisien, Profitabilitas ini di ukur dengan menggunakan Return On Asset (ROA) yang merupakan perbandingan antara laba sebelum pajak dengan total aset.

\section{TELAAH TEORI DAN PENGEMBANGAN HIPOTESIS 1.Telaah Teori \\ 1. Profitabilitas}

Menurut Sawir (2010) dalam Putri (2013) profitabilitas merupakan hasil akhir dari berbagai kebijakan dan keputusan manajemen. Rasio kemampuan laba akan memberikan jawaban akhir tentang efektivitas manajer perusahaan dan memberikan gambaran tentang 
efektivitas pengelolaan perusahaan. Menurut Riyanto (2008) dalam Putri (2013) Profitabilitas adalah kemampuan suatu bank dalam menghasilkan laba usaha dengan modal sendiri dan modal asing yang digunakan untuk menghasilkan laba tersebut.

Tingginya profitabilitas suatu perusahaan menunjukkan bahwa sebagian besar kinerja keuangan perusahaan tersebut dikatakan baik, Jika kinerja keuangan perusahaan dalam menghasilkan laba meningkat maka hal ini akan menunjukkan daya tarik investor dan calon investor dalam menanamkan modalnya keperusahaan. Bagi perbankan, keuntungan utama diperoleh dari selisih antara bunga simpanan yang diberikan kepada penyimpan dengan bunga pinjaman atau kredit yang disalurkan.

Profitabilitas suatu perusahanan diukur dengan kesuksesan perusahaan dan kemampuan menggunakan aktivanya secara produktif, dengan demikian profitabilitas suatu perusahaan dapat diketahui dengan memperbandingkan antara laba yang diperoleh dalam suatu periode dengan jumlah aktiva atau jumlah modal perusahaan tersebut.

Ada beberapa ukuran/rasio Profitailitas yang dipakai untuk mengukur kemampuan suatu perusahaan dalam mendapatkan laba yakni: a. Return On Asset (ROA), b. Return On Equity (ROE), dan c. Rasio Biaya Operasional Terhadap Pendapatan Operasional (BOPO). Rasio yang digunakan untuk mengukur Profitabilitas dalam penelitian ini diproksikan dengan Return On Assets (ROA), karena ROA memfokuskan kemampuan perusahaan untuk memperoleh laba dalam operasi perusahaan.

\section{Resiko Kredit}

Pengertian Kredit mempunyai dimensi yang beraneka ragam, dimulai dari arti kata "kredit" yang berasal dari bahasa Yunani "credere" yang berarti percaya. Kredit adalah kemampuan untuk melaksanakan suatu pembelian atau mengadakan suatu pinjaman dengan suatu janji, pembayaran akan dilaksanakan pada jangka waktu yang telah disepakati. Pengertian kredit yang lebih mapan untuk kegiatan perbankan di Indonesia adalah penyediaan uang/tagihan yang dapat dipersamakan dengan itu berdasarkan persetujuan/kesepakatan pinjam meminjam antara pihak bank dengan pihak lain yang mewajibkan pihak peminjam untuk membayar dengan jumlah bunga sebagai imbalan.

Resiko kredit adalah resiko yang timbul dalam hal debitur gagal memenuhi kewajiban untuk membayar angsuran pokok ataupun bunga sebagaimana telah disepakati dalam perjanjian kredit, resiko kredit juga merupakan salah satu resiko utama dalam pelaksanaan pemberian kredit bank dan hal ini juga akan berpengaruh terhadap kolektibilitas kredit.

Resiko kredit adalah Salah satu resiko yang dihadapi bank dimana tidak terbayarnya kredit yang telah diberikan. Resiko kredit atau default risk umumnya timbul dari berbagai kredit yang masuk dalam kategori bermasalah atau Non Performing Loan. Keberadaan Non Performing Loan dalam jumlah yang cukup banyak dapat menimbulkan kesulitan sekaligus menurunkan tingkat kesehatan bank yang bersangkutan. Oleh sebab itu bank dituntut untuk selalu menjaga kredit tidak berada dalam Non Performing Loan.

Besarnya Non Performing Loan yang diperbolehkan oleh Bank Indonesia saat ini adalah maksimal 5\%, jika melebihi 5\% maka akan mempengaruhi penilaian Tingkat Kesehatan Bank yang bersangkutan, yaitu akan mengurangi nilai Bank tersebut. Meskipun tidak dapat menghindari penuh resiko kredit, tetapi diusahakan supaya jumlah kredit yang bermasalah berada dalam batas yang wajar.

Rumus menghitung Resiko Kredit (Non Performing Loan /NPL) dapat dilihat dibawah ini:

$$
\text { NPL }=\frac{\text { Kredit Bermasalah }}{\text { Total Kredit }} \times 100 \%
$$




\section{Pengaruh Resiko Kredit Terhadap Profitabilitas.}

Non performing loan atau yang sering disebut kredit bermasalah dapat diartikan sebagai pinjaman yang mengalami kesulitan pelunasan akibat adanya faktor kesenjangan atau faktor eksternal di luar kemampuan kendali debitur. Rasio ini menunjukkan kemampuan manajemen bank dalam mengelola kredit bermasalah yang diberikan oleh bank. Artinya, semakin tinggi rasio ini maka akan semakin buruk kualitas kredit bank yang menyebabkan jumlah kredit bermasalah semakin besar maka kemungkinan suatu bank dalam kondisi bermasalah semakin besar yaitu kerugian yang diakibatkan tingkat pengembalian kredit macet. Silalahi(2011) dan Alifah (2014) pengaruh Non performing loan terhadap profitabilitas menunjukkan hasil bahwa Non performing loan tidak berpengaruh positif terhadap profitabilitas. Penelitian yang dilakukan oleh Novianty (2016) tentang pengaruh Non performing loan terhadap profitabilitas menunjukkan hasil bahwa Non performing loan memberikan pengaruh positif terhadap profitabilitas bank. Namun penelitian yang dilakukan oleh Sasongko (2014) dan Putri (2013) tentang pengaruh variabel Non performing loan terhadap profitabilitas menunjukkan hasil bahwa Non performing loan memberikan pengaruh negatif terhadap profitabilitas bank. Hal ini menunjukkan bahwa semakin besar kredit bermasalah yang terjadi pada suatu bank maka akan mengakibatkan profitabilitas bank tersebut menjadi buruk.

\section{Kecukupan Modal}

Menurut Novianty (2016) Kecukupan modal adalah ukuran yang menentukan jika bank memiliki modal yang memadai yang menawarkan perlindungan terhadap resiko yang terkait dengan penawaran kredit bank dan usaha keuangan lainnya. Kecukupan modal adalah suatu regulasi perbankan yang menetapkan suatu kerangka kerja mengenai bagaimana bank dan lembaga penyimpanan harus menangani permodalan mereka.

Modal yang dimaksud adalah modal inti dan modal pelengkap. Modal inti bank terdiri dari modal disetor, agio saham, cadangan umum, dan laba ditahan sedangkan yang termaksud modal pelengkap adalah cadangan revaluasi aktiva tetap, cadangan umum Penyisihan Penghapusan Aktiva Produktif (PPAP), modal agunan/pinjaman subordinasi.

Modal merupakan salah satu faktor penting dalam rangka pengembangan usaha bisnis dan menampung resiko kerugian. Besarnya modal suatu bank akan berpengaruh pada mampu atau tidaknya suatu bank secara efisien menjalankan kegiatannya, dan dapat mempengaruhi tingkat kepercayaan masyarakat (khususnya untuk masyarakat peminjam) terhadap kinerja bank. Penggunaan modal bank juga dimaksudkan untuk memenuhi segala kebutuhan bank guna menunjang kegiatan operasi bank, dan sebagai alat untuk ekspansi usaha. Kepercayaan masyarakat akan terlihat dari besarnya dana giro, deposito, dan tabungan yang melebihi jumlah setoran modal dari para pemegang sahamnya. Unsur kepercayaan ini merupakan masalah penting dan merupakan faktor keberhasilan pengelolaan suatu bank. Kecukupan modal dapat dihitung dengan Capital Adequacy Ratio (CAR)

Menurut Alifah (2014 :39) Capital Adequacy Ratio adalah sebuah ukuran atau rasio untuk kecukupan modal yang menunjukkan kemampuan bank dalam mempertahankan modal yang mencukupi dan kemampuan manajemen bank dalam mengidentifikasi, mengukur, mengawasi, dan mengontrol resiko-resiko yang timbul yang dapat berpengaruh terhadap besarnya modal. Perhitungan Capital Adequacy Ratio didasarkan pada prinsip bahwa setiap penanaman yang mengandung resiko harus disediakan jumlah modal sebesar persentase tertentu terhadap jumlah penanamannya. Bank yang termasuk bank sehat, apabila memiliki CAR paling sedikit sebesar 8\% sesuai dengan standar Bank for International Settlements (BIS). Sesuai denganpenilaian rasio CAR berdasarkan Surat Keputusan DIR BI No.30/12/KEP/DIR tanggal 30 April 1997 CAR minimal 8\%.

Perhitungan rasio CAR (Rifai, 2007) adalah sebagai berikut: 


$$
\mathrm{CAR}=\frac{\mathrm{MODAL}}{\mathrm{ATMR}} \times 100 \%
$$

\section{Pengaruh Kecukupan Modal Terhadap Profitabilitas}

Menurut Dendawijaya (2005) pengaruh tingkat kecukupan modal terhadap profitabilitas dapat dinyatakan sebagai berikut, tingkat kecukupan modal yang dijadikan sebuah indikator kesehatan suatu bank. Dapat diartikan sebagai kemampuan suatu bank untuk melakukan kegiatan operasional perbankan secara normal dan mampu memenuhi semua kewajibannya dengan cara-cara yang sesuai dengan peraturan perbankan yang berlaku. Rasio kecukupan modal merupakan faktor yang penting bagi bank dalam rangka pengembangan usaha dan menampung kerugian serta mencerminkan kesehatan bank yang bertujuan untuk menjaga kepercayaan masyarakat kepada perbankan, melindungi dana masyarakat pada bank bersangkutan dan untuk memenuhi ketetapan standar BIS. Dengan permodalan yang kuat akan mampu menjaga kepercayaan masyarakat terhadap bank yang bersangkutan, sehingga masyarakat percaya untuk menghimpun dana pada bank tersebut, dana yang terhimpun tersebut kemudian disalurkan kembali oleh bank kepada masyarakat dalam bentuk kredit. Dalam bentuk kredit ini dapat mendorong pendapatan sehingga menghasilkan bunga, dari bunga itulah bank mendapatkan laba atau profit. Dengan tingkat laba atau profitabilitas inilah bank dapat meningkatkan struktur permodalan yang kuat sehingga dapat membentuk kondisi keuangan yang sehat. Penelitian yang dilakukan oleh Alifah(2014) dan Novianty (2016) tentang pengaruh variabel Capital adequacy Ratio terhadap variabel profitabilitas bahwa variabel Capital adequacy Ratio berpengaruh positif dan signifikan terhadap profitabilitas bank.

\section{Hutang}

Menurut Pandia (2012) Hutang pada bank identik dengan sumber dana bank itu sendiri, karena sebagian besar sumber dana bank berasal dari hutang (liabilities) bank terhadap nasabahnya dan merupakan kewajiban yang harus dipenuhi bilamana dana tersebut ditarik atau jatuh tempo.

Menurut Sutrisno (2003:9) dalam Irawan (2012) hutang adalah suatu modal yang berasal dari pinjaman baik dari bank, lembaga keuangan, maupun dengan mengeluarkan surat hutang, dan atas penggunaan ini perusahaan memberikan kompensasi berupa bunga yang menjadi beban tetap bagi perusahaan. Jadi hutang itu adalah suatu modal yang berasal dari pinjaman dari berbagai pihak yang di masa mendatang harus dibayarkan kembali kepada pihak tersebut disertai syarat-syarat tertentu. Menurut Hartono ( 2000) dalam Irawan (2012), menyebutkan juga bahwa hutang itu mengandung resiko. Semakin tinggi resiko perusahaan, semakin tinggi tingkat profitabilitas yang diharapkan sebagai imbalan terhadap tingginya resiko dan sebaliknya. Semakin rendah resiko perusahaan, semakin rendah tingkat profitabilitas yang diharapkan sebagai imbalan rendahnya resiko.

Rasio yang digunakan untuk mengukur hutang adalah Debt to Equity Ratio (DER). Debt to Equity Ratio merupakan rasio yang digunakan untuk menilai hutang dengan ekuitas. Caranya adalah dengan membandingkan antara total hutang dengan total ekuitas. Pada buku The Investing Policy (TIP) dalam Teguh Hidayat (2011), mengatakan bahwa batas kewajaran utang sebuah perusahaan adalah maksimal tiga kali modalnya, atau DER-nya 300\%, dengan catatan utang-utang tersebut bukan merupakan utang yang 'berbahaya'. Batasan tersebut didasarkan pada kebijakan bank lokal, yang rata-rata hanya mau memberikan pinjaman kepada perusahaan dengan catatan utang atau kewajiban yang tidak lebih besar dari 2.0 hingga 2.5 kali modalnya (DER-nya maksimal 250\%). Sementara beberapa bank asing ada 
yang mau memberikan pinjaman kepada perusahaan dengan DER 350\% atau bahkan 400\%. Sehingga rata-rata batas maksimal DER 300\%. Jadi kalau ada perusahaan yang utangnya lebih besar dari tiga kali modalnya, maka meskipun utang-utangnya termasuk utang yang sehat, namun tetap saja sahamnya tidak ideal lagi. Rasio ini diukur dengan rumus sebagai berikut:

$$
\mathrm{DER}=\frac{\text { Total Hutang }}{\text { Total Ekuitas }} \times 100 \%
$$

\section{Pengaruh Hutang Terhadap Profitabilitas}

Penggunaan hutang merupakan salah satu keputusan penting yang dibuat manajer pendanaan dalam rangka meningkatkan profitabilitas perusahaan. Hartono (2000 : 254), menyebutkan bahwa hutang itu mengandung resiko. Semakin tinggi resiko suatu perusahaan, semakin tinggi tingkat profitabilitas yang diharapkan sebagai imbalan terhadap tingginya resiko dan sebaliknya semakin rendah resiko perusahaan, semakin rendah tingkat profitabilitas yang diharapkan sebagai imbalan terhadap rendahnya resiko. Menurut Pandia (2012:181) Hutang pada bank identik dengan sumber dana bank itu sendiri, karena sebagian besar sumber dana bank berasal dari hutang (liabilities) bank terhadap nasabahnya dan merupakan kewajiban yang harus dipenuhi bilamana dana tersebut ditarik atau jatuh tempo. Pandia (2012: 182) semakin besar dana yang dapat dihimpun oleh suatu bank maka semakin besar kemampuan bank dalam menyalurkan kredit, ini berarti semakin besar jumlah pendapatan suatu bank. Pengaruh hutang terhadap profitabilitas pada berbagai penggunaan modal asing, secara teori dapat dikatakan bahwa semakin tinggi kemampuan perusahaan untuk menghasilkan laba dengan menggunakan modal asing (hutang) dan modal sendiri (dengan tingkat bunga tetap) maka penggunaan modal asing yang memiliki peluang besar dalam meningkatkan profitabilitas. Dengan kata lain, dalam keadaan demikian perusahaan yang menggunakan hutang akan lebih besar memperoleh kenaikan profitabilitas yang besar jika dibandingkan dengan perusahaan lain yang mempunyai hutang lebih kecil.

\section{Pendapatan Bunga}

Menurut Kasmir (2008:131) Pendapatan Bunga (Bunga Pinjaman) adalah bunga yang diberikan kepada para peminjam atau harga yang harus dibayar nasabah peminjam kepada bank. Rasio yang digunakan untuk mengukur pendapatan bunga adalah Net Interest Margin (NIM). NIM menunjukkan kemampuan bank dalam menghasilkan pendapatan dari bunga dengan melihat kinerja bank dalam menyalurkan kredit, mengingat pendapatan operasional sangat tergantung dari selisih bunga dari kredit yang disalurkan. Pendapatan diperoleh dari bunga yang diterima dari pinjaman yang diberikan dikurangi dengan biaya bunga dari sumber dana yang dikumpulkan. NIM suatu bank sehat bila memiliki NIM diatas $2 \%$. Untuk dapat meningkatkan perolehan NIM perlu menekan biaya dana, biaya dana adalah bunga yang dibayarkan oleh bank kepada masing-masing sumber dana bank yang bersangkutan. Secara keseluruhan, biaya yang harus dikeluarkan oleh bank akan menentukan berapa persen bank akan menetapkan tingkat bunga kredit yang diberikan kepada nasabahnya untuk mendapatkan pendapatan bersih bank dari bunga.

Dalam hal ini tingkat suku bunga sangat menentukan besarnya NIM. Rasio ini dapat dihitung dengan rumus:

$$
\mathrm{NIM}=\frac{\text { Pendapatan Bunga Bersih }}{\text { Rata-rata Aktiva Produktif }} \times 100 \%
$$




\section{Pengaruh Pendapatan Bunga Terhadap Profitabilitas}

Menurut Kasmir (2008) Pendapatan Bunga (Bunga Pinjaman) adalah bunga yang diberikan kepada para peminjam atau harga yang harus dibayar nasabah peminjam kepada bank. Rasio Net Interest Margin (NIM) digunakan untuk mengukur kemampuan manajemen bank dalam mengelola aktiva produktifnya untuk menghasilkan pendapatan bunga bersih. Pendapatan bunga bersih diperoleh dari pendapatan bunga dikurangi beban bunga. Semakin besar rasio ini maka akan meningkatkan pendapatan bunga atas aktiva produktif yang dikelola bank sehingga kemungkinan suatu bank dalam kondisi bermasalah semakin kecil atau tingkat profitabilitasnya semakin besar.

\section{Kerangka Pemikiran}

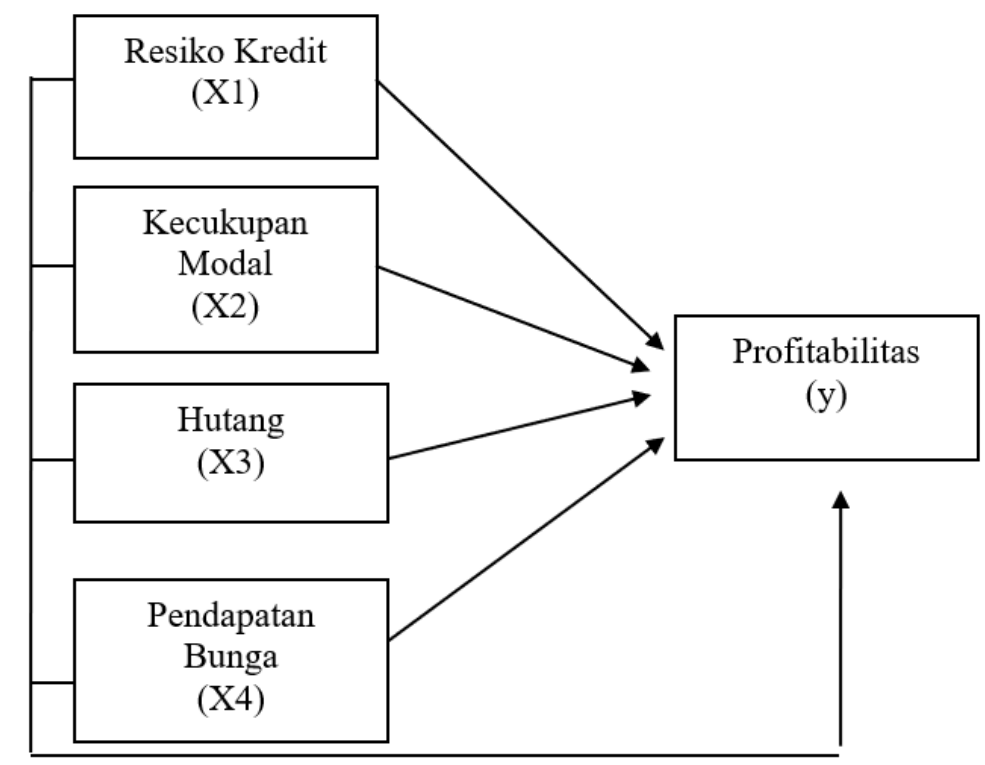

Gambar 1. Kerangka Pikir

\section{METODE PENELITIAN}

\section{Populasi dan Sampel}

Populasi dalam penelitian ini adalah perusahaan perbankan yang terdaftar di BEI sejak 2011 -2015 sebanyak 36 perusahaan dengan jumlah populasi sebesar 180 yaitu 36 x 5 tahun . Alasan pemilihan obyek penelitian ini adalah berdasarkan pada pertimbangan, data laporan keuangan perusahaan telah tersedia sehingga mudah mengaksesnya, dan data tersebut telah diaudit oleh akuntan publik.

Pemilihan sampel penelitian menggunakan metode purposive sampling, dengan kriteria pemilihan sampel sebagai berikut:

1. Perusahaan perbankan yang terdaftar di BEI adalah 36 perusahaan.

2. Perusahaan yang tidak menerbitkan laporan keuangan dengan lengkap selama tahun penelitian (2011 - 2015), adalah kosong.

3. Perusahaan yang memiliki data yang lengkap selama periode penelitian untuk faktorfaktor yang diteliti, yaitu Resiko Kredit, Kecukupan Modal, Hutang, Pendapatan Bunga dan Profitabilitas, sebanyak 12 perusahaan.

4. Jumlah sampel sebagai berikut: $36-12=24$, Tahun penelitian 5, maka sampel penelitian sebanyak $24 \times 5$ tahun $=120$.

\section{Operasionalisasi Variabel}

a. Variabel Dependen 
Variabel dependen yaitu variabel yang dipengaruhi atau tergantung oleh variabel lain. Variabel dependen dalam penelitian ini adalah profitabilitas yang diproksikan menggunakan variabel ROA. Profitabilitas adalah kemampuan perusahaan memperoleh laba dalam hubungannya dengan penjualan, total aktiva maupun modal sendiri (Sartono 2001). Pada penelitian ini rasio yang digunakan adalah Return On Assets (ROA).

$$
\text { ROA }=\frac{\text { Laba Sebelum Pajak }}{\text { Total Asset }} \times 100 \%
$$

\section{b. Variabel Independen}

Variabel Independen, yaitu variabel bebas atau tidak berpengaruh oleh variabel lain. Variabel independen yang digunakan dalam penelitian ini adalah adalah resiko kredit dan kecukupan modal.

\section{Resiko Kredit}

Menurut Kasmir (2012: 228) Resiko Kredit adalah rasio yang digunakan untuk mengukur resiko terhadap kredit yang disalurkan dengan membandingkan kredit macet dengan jumlah kredit yang disalurkan. Dalam penelitian ini resiko kredit menggunakan Net Performing Loan (NPL).

$$
\text { NPL }=\frac{\text { Kredit Bermasalah }}{\text { Total Kredit }} \times 100 \%
$$

\section{Kecukupan Modal}

Kecukupan modal adalah ukuran yang menentukan jika bank memiliki modal yang memadai yang menawarkan perlindungan terhadap resiko yang terkait dengan penawaran kredit bank dan usaha keuangan lainnya. Dalam penelitian ini kecukupan modal menggunakan CapitalAdequacy Ratio (CAR).

$$
\mathrm{CAR}=\frac{\text { Modal }}{\mathrm{ATMR}} \times 100 \%
$$

\section{Utang}

Menurut Sutrisno (2003:9), hutang adalah suatu modal yang berasal dari pinjaman baik dari bank, lembaga keuangan, maupun dengan mengeluarkan surat hutang, dan atas penggunaan ini perusahaan memberikan kompensasi berupa bunga yang menjadi beban tetap bagi perusahaan. Dalam penelitian ini hutang menggunakan Debt to Equity Ratio (DER).

$$
\mathrm{DER}=\frac{\text { Total Hutang }}{\text { Total Equity }} \times 100 \%
$$

\section{Pendapatan Bunga}

Pendapatan Bunga (Bunga Pinjaman) adalah bunga yang diberikan kepada para peminjam atau harga yang harus dibayar nasabah peminjam kepada bank. Rasio yang digunakan untuk mengukur pendapatan bunga adalah Net Interest Margin (NIM). 


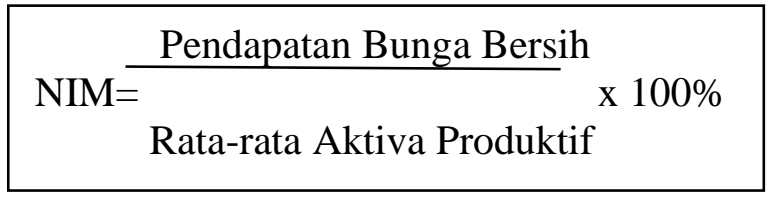

\section{Teknik Pengumpulan Data}

Dalam penelitian ini digunakan data sekunder yaitu data yang diperoleh melalui studi pustaka dengan mempelajari berbagai tulisan yang berhubungan dengan Resiko Kredit, Kecukupan Modal, Hutang, Pendapatan Bunga, dan Profitabilitas. Data yang dikumpulkan yaitu Laporan Keuangan Perbankan yang terdaftar di Bursa Efek Indonesia periode 20112015 yang dapat diakses melalui internet dengan situs: www.idx.co.id.

\section{Teknik Analisis}

Penelitian ini menggunakan teknik analisis regresi linear berganda (multiple regression analysis model) yaitu analisis yang digunakan untuk mengetahui besarnya pengaruh variable independen terhadap variable dependen.

Adapun model regeresi berganda dalam penelitian ini sebagai berikut:

$$
\mathrm{Y}=\mathrm{a}+\mathrm{b} 1 \mathrm{X} 1+\mathrm{b} 2 \mathrm{X} 2+\mathrm{b3X3}+\mathrm{b} 4 \mathrm{X} 4+\mathrm{e}
$$

Keterangan :

$\mathrm{a}=$ Konstanta,

b1, b2, b3, b4= Koefisien regeresi variable,

$\mathrm{Y}=\mathrm{ROA}, \mathrm{X} 1=\mathrm{NPL}, \mathrm{X} 2=\mathrm{CAR}, \mathrm{X} 3=\mathrm{DER}, \mathrm{X} 4=\mathrm{NIM}, \mathrm{e}=$ error

Data penelitian ini dianalisis dengan alat statistik, yang terdiri atas:

\section{a. Pengujian Asumsi Klasik}

Sebelum melakukan analisis regresi linear berganda terlebih dahulu dilakukan pengujian asumsi klasik untuk membuktikan apakah hipotesis yang digunakan model regresi linear telah memenuhi beberapa asumsi klasik yang diisyaratkan agar hasil regresi yang diperoleh merupakan estimasi yang tepat dan juga data yang diteliti tidak bias. Uji asumsi klasik terdiri dari :Uji Normalitas, Uji Multikolonieritas, Uji AutokorelasiUji, dan Heteroskedastisitas

\section{b. Uji Hipotesis}

Dalam penelitian ini hipotesis diuji melalui dua macam pengujian yaitu Uji $t$ atau uji parsial dan Uji F atau uji simultan

\section{HASIL PENELITIAN DAN PEMBAHASAN}

\section{Hasil Uji Asumsi Klasik}

Hipotesis penelitian diuji dengan menggunakan teknik analisis regresi linier berganda. Dalam analisis regresi linier harus terpenuhi beberapa pengujian asumsi klasik, yang antara lain adalah asumsi normalitas, multikolinearitas, autokorelasi, dan heteroskedastisitas. Asumsi tersebut harus dapat terpenuhi agar dapat diperoleh persamaan regresi yang akurat.

\section{a. Uji Normalitas}

Uji normalitas bertujuan untuk menguji apakah dalam model regresi, variabel pengganggu atau residual terdistribusi normal. Uji-t dinyatakan valid jika residual terdistribusi normal. Uji normalitas yang digunakan adalah One-Sample Kolmogorov-Smirnov Test.

Tabel 1. Hasil Uji Normalitas

\begin{tabular}{|l|l|r|}
\hline \multicolumn{2}{|c|}{ One-Sample Kolmogorov-Smirnov Test } \\
\hline \multicolumn{2}{|c|}{} & \multicolumn{1}{|c|}{ Unstandardized Residual } \\
\hline N & & 120 \\
\hline Normal Parameters & & $0 \mathrm{E}-7$ \\
\hline
\end{tabular}




\begin{tabular}{|l|l|r|}
\hline & $\begin{array}{l}\text { Std. } \\
\text { Deviation }\end{array}$ &, 01454397 \\
\hline \multirow{2}{*}{$\begin{array}{l}\text { Most Extreme } \\
\text { Differences }\end{array}$} & Absolute &, 121 \\
\cline { 2 - 3 } & Positive &, 100 \\
\cline { 2 - 3 } & Negative &,- 121 \\
\hline Kolmogorov-Smirnov Z & 1,323 \\
\hline Asymp. Sig. (2-tailed) &, 060 \\
\hline \multicolumn{2}{|l|}{ a. Test distribution is Normal. } \\
\hline \multicolumn{2}{|l|}{ b. Calculated from data. } \\
\hline
\end{tabular}

Sumber: Data diolah dari SPSS v. 20

Hasil uji normalitas Kolmogorov-Smirnov pada variabel NPL, CAR, DER dan NIM menunjukkan bahwa nilai Asymp. Sig (2 tailed) sebesar 0,060 atau 0,060 > 0,050. Hal itu menunjukkan bahwa hipotesis nol diterima dan berarti secara keseluruhan variabel berdistribusi normal.

\section{b. Uji Multikolinearitas}

Uji multikolinearitas bertujuan untuk menguji apakah dalam model ditemukan adanya korelasi antar variabel independen. Model regresi yang baik seharusnya tidak terjadi korelasi di antara variabel independen. Pada penelitian ini uji multikolinearitas dilakukan dengan melihat nilai Variance Inflation Factor (VIF) pada model regresi. Jika nilai VIF melebihi nilai 10, variabel tersebut memiliki multikolinearitas yang tinggi. Tabel 2 menunjukkan hasil uji multikolinearitas yang dimaksud.

Tabel 2. Hasil Uji Multikolinearitas

Coefficients $^{\mathbf{a}}$

\begin{tabular}{|c|c|c|c|c|c|c|c|c|}
\hline \multirow{2}{*}{\multicolumn{2}{|c|}{ Model }} & \multicolumn{2}{|c|}{$\begin{array}{l}\text { Unstandardize } \\
\text { d Coefficients }\end{array}$} & \multirow{2}{*}{$\begin{array}{c}\text { Standardized Coefficients } \\
\text { Beta }\end{array}$} & \multirow[t]{2}{*}{$\mathrm{t}$} & \multirow[t]{2}{*}{ Sig. } & \multicolumn{2}{|c|}{$\begin{array}{c}\text { Collinearity } \\
\text { Statistics }\end{array}$} \\
\hline & & B & $\begin{array}{l}\text { Std. } \\
\text { Error }\end{array}$ & & & & $\begin{array}{c}\text { Toleran } \\
\text { ce }\end{array}$ & VIF \\
\hline \multirow{5}{*}{1} & (Constant & ,022 & ,009 & & 2,588 & ,011 & & \\
\hline & NPL &,- 336 & ,080 &,- 344 & 4223 & ,000 & ,778 & 1,286 \\
\hline & CAR &,- 020 & ,014 &,- 123 & $1431^{-}$ &, 155 & 693 & 1,443 \\
\hline & DER &,- 002 & ,001 &,- 233 & $2.473^{-}$ & ,015 & ,582 & 1,717 \\
\hline & NIM & ,335 & ,057 & ,444 & 5,917 & ,000 & ,914 & 1,094 \\
\hline
\end{tabular}

a. Dependent Variable: ROA

Sumber: Data diolah dari SPSS v. 20

Berdasarkan tabel diatas, terlihat bahwa tolerance value $>0,10$ dan $\mathrm{VIF}<10$, sehingga dapat disimpulkan bahwa diantara variabel bebas tersebut tidak terdapat hubungan multikolinearitas. Dari hasil uji ini maka dapat disimpulkan bahwa semua variabel bebas yang dipakai dalam penelitian ini lolos uji gejala multikolineritas 


\section{c. Uji Autokorelasi}

Autokorelasi terjadi karena adanya korelasi antara satu variabel gangguan dan variabel gangguan yang lain. Untuk mengetahui ada tidaknya masalah autokorelasi pada model tersebut, digunakan uji Durbin Watson. Hasil uji yang dimaksud di tunjukkan pada table ini.

Tabel 3. Hasil Uji Autokorelasi

\begin{tabular}{|l|r|r|r|r|r|}
\hline $\begin{array}{l}\text { Mode } \\
1\end{array}$ & R & R Square & $\begin{array}{c}\text { Adjusted R } \\
\text { Square }\end{array}$ & $\begin{array}{c}\text { Std. Error of the } \\
\text { Estimate }\end{array}$ & Durbin-Watson \\
\hline 1 &, $639^{\mathrm{a}}$ &, 408 &, 387 &, 0147947 & 1,862 \\
\hline
\end{tabular}

a. Predictors: (Constant), NIM, NPL, CAR, DER

b. Dependent Variable: ROA

Sumber: Data diolah dari SPSS v. 20

Hasil uji Durbin-Watson menunjukkan besaran nilai d sebesar 1,862. Nilai ini dibandingkan dengan nilai Durbin-Watson $(\mathrm{k}, \mathrm{n})$ dengan $\mathrm{k}$ menunjukkan jumlah variabel independen, yaitu 4, dan $\mathrm{n}$ adalah jumlah sampel yang berjumlah 120. Apabila nilai d yang didapat tergolong pada jarak nilai $\mathrm{du}<\mathrm{d}<4$-du, dikatakan tidak ada autokorelasi positif atau negatif. Nilai $\mathrm{du}=1,7715$ dan $\mathrm{dl}=1,6339$ sehingga $1,7715<1,862<4-1,7715$. Hasil tersebut menunjukkan bahwa model yang digunakan tidak ada autokorelasi positif maupun negatif (bebas uji autokorelasi) pada persamaan regresi dalam penelitian ini.

\section{d. Uji Heteroskedastisitas}

Uji heteroskedastisitas digunakan untuk mengetahui ada tidaknya salah satu penyimpangan asumsi klasik, yaitu varian dari residual tidak konstan. Model regresi yang baik adalah yang homoskedastisitas atau tidak terjadi heteroskedastisitas.

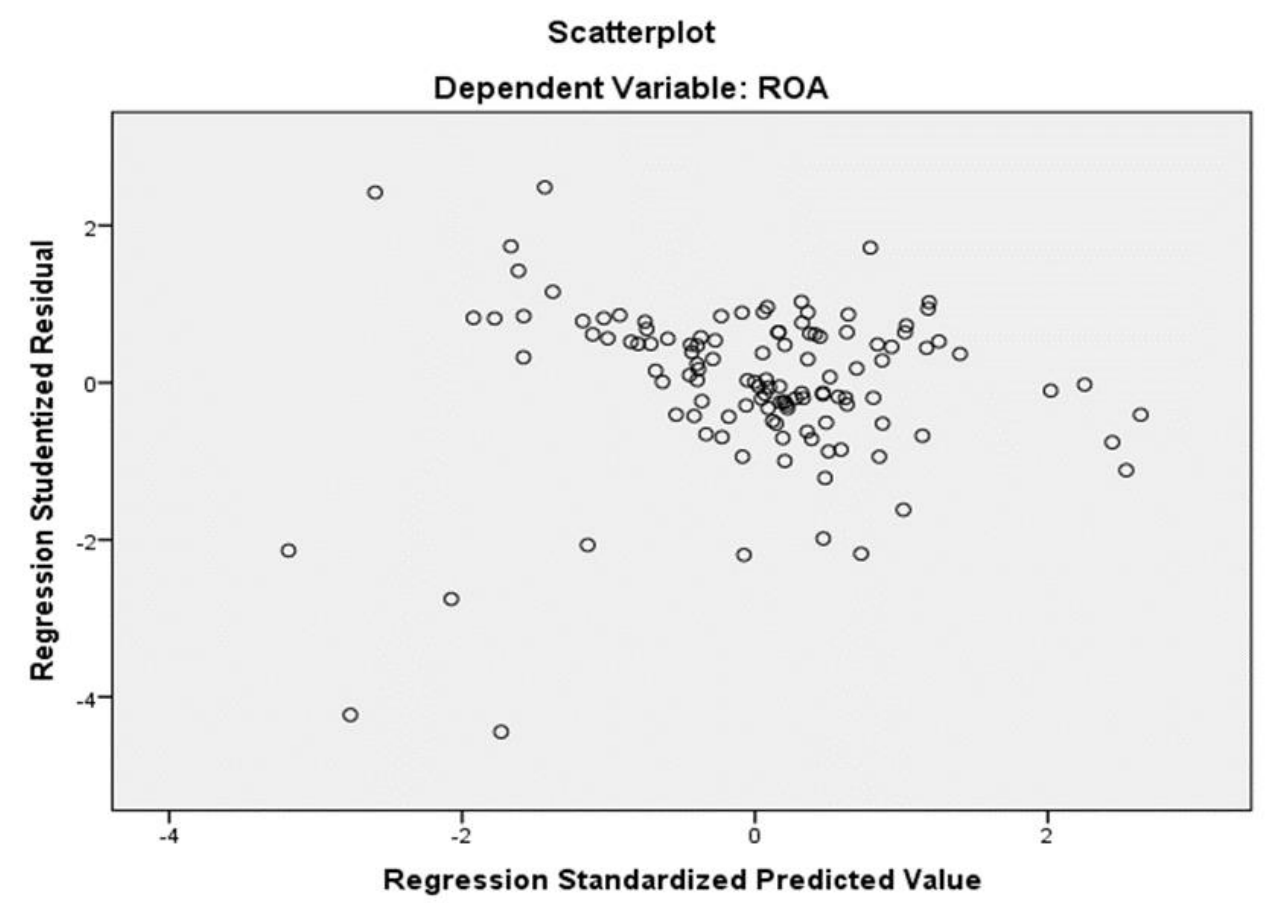

Gambar 1. Hasil Uji Heteroskedastisitas

Sumber: Data diolah dari SPSS v. 20

Dari grafik scatterplots terlihat bahwa titik-titik menyebar secara acak dan tersebar baik diatas maupun dibawah angka 0 pada sumbu Y. Hal ini dapat disimpulkan bahwa tidak terjadi heteroskedastisitas pada model regresi, sehingga model regresi layak digunakan. 
Analisis data dalam penelitian ini menggunakan metode analisis regresi berganda (multiple regression analysis).

Tabel 5. Hasil Regresi Berganda

\section{Hasil Uji Regresi Linear Berganda}

\begin{tabular}{|c|c|c|c|}
\hline \multirow{2}{*}{\multicolumn{2}{|c|}{ Model }} & \multicolumn{2}{|c|}{ Unstandardized Coefficients } \\
\hline & & $\mathrm{B}$ & Std. Error \\
\hline \multirow{5}{*}{1} & (Constant) & 022 & ,009 \\
\hline & NPL &,- 336 & ,080 \\
\hline & CAR &,- 020 & ,014 \\
\hline & DER &,- 002 & ,001 \\
\hline & NIM & ,335 & 057 \\
\hline
\end{tabular}

Sumber: Data diolah dari SPSS v. 20

Berdasarkan tabel tersebut, makadapat disusun persamaan regresi sebagai berikut:

$\mathrm{ROA}=0,022-0,336 \mathrm{NPL}-0,020 \mathrm{CAR}-0,002 \mathrm{DER}+0,335 \mathrm{NIM}+0$

Keterangan:

ROA = nilai imbal hasil aset perusahaan yang diteliti

$\mathrm{NPL}=$ nilai rasio kredit bermasalah perusahaan yang diteliti

$\mathrm{CAR}=$ nilai rasio kecukupan modal perusahaan yang diteliti

DER = nilai rasio hutang perusahaan yang diteliti

$\mathrm{NIM}=$ nilai rasio pendapatan bunga perusahaan yang diteliti

$\mathrm{a}=$ Konstanta

$\mathrm{e}=$ Error

Dari tabel diatas dapat dijelaskan bahwa:

- Konstanta sebesar 0,022 menyatakan bahwa jika variabel independen dianggap konstan, maka rata-rata ROA perusahaan perbankan sebesar 0,022 atau 2,2\%.

- Koefisien regresi NPL sebesar -0,336 menyatakan bahwa setiap penurunan NPL sebesar 1\% akan meningkatkan ROA sebesar 33,6\%.

- Koefisien regresi CAR sebesar -0,020 menyatakan bahwa setiap penurunan CAR sebesar $1 \%$ akan meningkatkan ROA sebesar $2 \%$

- Koefisien regresi DER sebesar -0,002 menyatakan bahwa setiap penurunan DER sebesar $1 \%$ akan meningkatkan ROA sebesar $0,2 \%$.

- Koefisien regresi NIM sebesar 0,335 menyatakan bahwa setiap peningkatan NIM sebesar $1 \%$ akan meningkatkan ROA sebesar33,5\%.

Persamaan regresi di atas selanjutnya akan diuji dengan uji statistic, yaitu untuk mengetahui pengaruh secara parsial dengan menggunakan uji t serta untuk mengetahui pengaruh secara simultan dengan menggunakan uji F.

\section{Pengujian Hipotesis}

Dari pengujian asumsi klasik dapat disimpulkan bahwa data yang ada berdistribusi normal, tidak terdapat multikolinearitas, autokorelasi dan heteroskedastisitas, sehingga memenuhi syarat untuk melakukan pengujian hipotesis. Pengujian hipotesis adalah sebagai berikut:

\section{a. Uji Parsial (Uji t)}

Uji t dilakukan untuk mengetahui pengaruh antara variabbel-variabel independen terhadap variabel dependen secara parsial (individu). Pengujian ini dilakukan dengan membandingkan nilai signifikan t yang ditunjuk oleh signifikan dari t pada tabel 4.10 dengan 
tingkat signifikan yang diambil sebesar 0,05 dan t hitung dibandingkan dengan t tabel.jika nilai sig. $\mathrm{T}<0,05$ dan $\mathrm{t}$ hitug $>\mathrm{t}$ tabel maka variabel independen berpengaruh dan signifikan terhadap variabel dependen.

Tabel 6. Hasil Uji Parsial (Uji t)

Coefficients $^{\text {a }}$

\begin{tabular}{|c|c|c|c|c|c|c|}
\hline \multirow{2}{*}{\multicolumn{2}{|c|}{ Model }} & \multicolumn{2}{|c|}{$\begin{array}{c}\text { Unstandardized } \\
\text { Coefficients }\end{array}$} & $\begin{array}{c}\text { Standardized } \\
\text { Coefficients }\end{array}$ & \multirow[t]{2}{*}{$\mathrm{t}$} & \multirow[t]{2}{*}{ Sig. } \\
\hline & & B & Std. Error & Beta & & \\
\hline \multirow{5}{*}{1} & (Constant) & 022, & ,009 & & 2,588 & ,011, \\
\hline & NPL &,- 336 & ,080 &,- 344 & $-4,223$ & ,000 \\
\hline & CAR &,- 020 & ,014 &,- 123 & $-1,431$ & , 155 \\
\hline & DER &,- 002 & ,001 &,- 233 & $-2,473$ & ,015 \\
\hline & NIM & ,335 & ,057 & ,444 & 5,917 &, 000 \\
\hline
\end{tabular}

a. Dependent Variable: ROA

Sumber: Data diolah dari SPSS v. 20

Berdasarkan output spss 20 bahwa variabel NPL berpengaruh negatif dan signifikan terhadap ROA, nilai $\mathrm{t}$ hitung 4,223 $>\mathrm{t}$ abel 1,658 dan tingkat sig $0,00<0,05$. Variabel CAR tidak berpengaruh terhadap ROA, nilai t hitung 1,431 < t tabel 1,658 dan tingkat sig 0,155> 0,05 . Variabel DER berpengaruh negatif dan signifikan terhadap ROA, nilai t hitung 2,473 >t tabel 1,658 dan tingkat sig 0,015 $<0,05$. Variabel NIM berpengaru positif dan signifikan terhadap ROA, nilai t hitung 5,917 > t tabel 1,658 dan tingkat sig 0,000 $<0,05$.

\section{b. Uji Signifikansi Simultan (Uji F)}

Pengujian ini dimaksudkan untuk mengetahui pengaruh antara variabel independen terhadap variabel dependen secara bersama-sama (simultan). Signifikansi model regresi secara simultan diuji dengan melihat perbandingan antara $f$ tabel dengan $f$ hitung. Selain itu akan dilihat nilai signifikansi, dimana jika nilai signifikan diawah 0,05 maka variabel independen dinyatakan berpengaruh terhadap variabel dependen. Hasil penelitian di tunjukkan pada tabel berikut ini:

Tabel 7. Uji Signifikansi Simultan (Uji F)

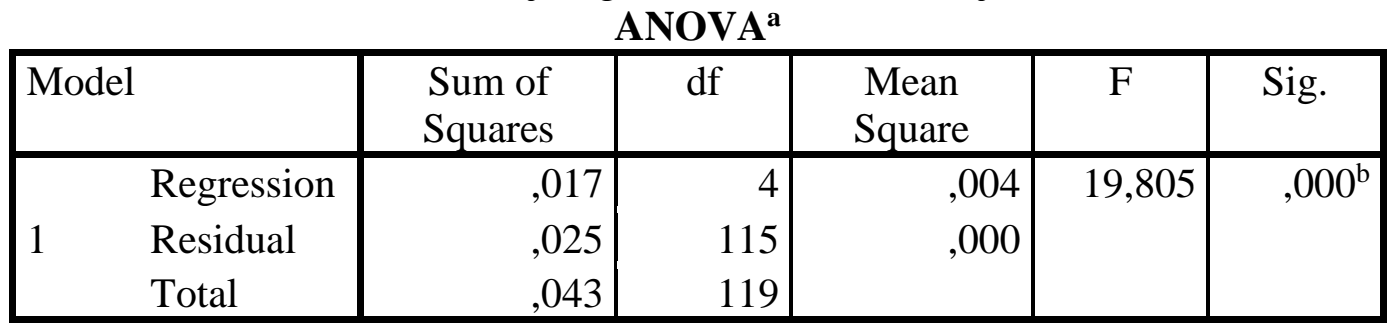

a. Dependent Variable: ROA

b. Predictors: (Constant), NIM, NPL, CAR, DER

Sumber: Data diolah dari SPSS v. 20

Berdasarkan hasil tersebut nampak bahwa nilai f hitung 19,805 > f tabel 2,450 dan tingkat sig $0,00<0,05$ yang artinya bahwa NPL, CAR, DER, dan NIM secara simultan berpengaruh signifikan terhadap ROA.

\section{Pembahasan}

\section{a. Pengaruh Resiko Kredit (Non Performing Loan) terhadap Profitabilitas ( ROA)}

Koefisien regresi variabel NPL bernilai negatif sebesar -0,336. Nilai signifikansi menunjukkan 0,000 yang nilainya lebih kecil daripada $\alpha=0,05$ dan nilai $\mathrm{t}$ hitung 4,223 >t 
tabel 1,658. Hal ini menunjukkan variabel NPL berpengaruh terhadap variabel ROA. Penelitian ini konsisten dengan penelitian Putri (2013) dan Sasongko (2014). Hasil penelitian tersebut menunjukkan bahwa variabel NPL menunjukkan pengaruh negatif dan signifikan terhadap ROA. Sehingga hipotesis yang menyatakan terdapat pengaruh negatif dan signifikan resiko kredit terhadap profitabilitas diterima.

Resiko kredit umumnya timbul dari berbagai kredit yang masuk dalam kategori bermasalah. Keberadaan kredit bermasalah dalam jumlah yang cukup banyak dapat menurunkan tingkat kesehatan bank yang bersangkutan. Besarnya NPL perbankan dapat diartikan bahwa perusahaan memiliki resiko kredit bermasalah yang besar sehingga mengakibatkan penurunan laba. Apabila suatu bank memiliki kondisi NPL tinggi maka akan memperbesar biaya baik biaya pencadangan aktiva produktif maupun biaya lainnya, sehingga berpotensi terhadap kerugian bank. Hasil perhitungan dalam penelitian ini menunjukkan hal yang sejalan dengan pernyataan tersebut. Besarnya NPL perbankan dapat diartikan bahwa perusahaan memiliki resiko kredit macet yang besar sehingga mengakibatkan laba menurun. Dari data yang diperoleh, NPL Bank yang terdaftar di Bursa Efek Indonesia periode 20112015 relatif kecil, dengan rata-rata NPL sebesar 2,19\%; masih di bawah batas maksimum yang ditetapkan Bank Indonesia yaitu 5\%.

\section{b. Pengaruh Kecukupan Modal (Capital Adequacy Ratio) terhadap Profitabilitas (Return On Asset)}

Koefisien regresi variabel CAR bernilai negatif sebesar -0,020. Nilai signifikansi menunjukkan angka sebesar 0,155 yang nilainya lebih besar daripada $\alpha=0,05$ dan nilai $\mathrm{t}$ hitung $1,431<\mathrm{t}$ tabel 1,658 . Hal ini menunjukkan variabel CAR tidak berpengaruh terhadap variabel ROA. Hasil penelitian ini konsisten dengan penelitian Silalahi (2011). Hasil penelitian tersebut menunjukkan bahwa variabel CAR tidak berpengaruh terhadap ROA. Sehingga hipotesis yang menyatakan terdapat pengaruh positif dan signifikan kecukupan modal terhadap profitabilitas ditolak.

Secara teori CAR digunakan untuk mengukur kemampuan bank dalam mempertahankan modal yang mencukupi dan kemampuan bank dalam mengidentifikasi, mengukur, mengawasi, dan mengontrol resiko-resiko yang timbul yang dapat berpengaruh terhadap besarnya modal, dengan permodalan yang tinggi bank dapat leluasa untuk menempatkan dananya kedalam investasi yang menguntungkan. Semakin besar nilai CAR maka semakin besar juga nilai ROA. Hasil perhitungan dalam penelitian ini menunjukkan hal yang berbanding terbalik dengan pernyataan tersebut, hasil perhitungan dalam penelitian ini menunjukkan bahwa CAR tidak berpengaruh terhadap ROA.

Dari data yang diperoleh, CAR Bank yang terdaftar di Bursa Efek Indonesia periode 2011-2015 relatif tinggi dengan rata-rata CAR Bank yang terdaftar di Bursa Efek Indonesia periode 2011-2015 sebesar 18,89\%, masih di atas batas minimum yang ditetapkan Bank Indonesia yaitu $8 \%$, kemudian terdapat beberapa peningkatan rasio CAR yang seharusnya diikuti dengan meningkatnya rasio ROA tetapi malah justru rasio ROA mengalami penurunan, juga terdapat penurunan rasio CAR yang seharusnya diikuti dengan menurunnya rasio ROA tetapi malah justru rasio ROA mengalami peningkatan. Hal ini terjadi karena ketika modal yang tinggi disalurkan ke masyarakat tetapi bank tidak mampu mengolah modal dengan baik maka mengakibatkan laba menurun karena adanya biaya-biaya operasional dan biaya lainnya. Besar kecilnya CAR belum tentu menyebabkan besar kecilnya keuntungan bank. Bank yang memiliki modal besar namun tidak dapat menggunakan modalnya secara efektif untuk menghasilkan laba maka modal pun tidak akan berpengaruh signifikan terhadap profitabilitas bank. Dengan adanya upaya bank untuk menjaga kecukupan modal bank, maka bank tidak mudah mengeluarkan dana mereka untuk pendanaan karena hal tersebut dapat 
memberikan resiko yang besar. Hal tersebut menyebabkan CAR tidak menjadi faktor yang berpengaruh signifikan terhadap profitabilitas bank.

\section{c. Pengaruh Hutang (Debt To Equity Rasio) terhadap Profitabilitas (Return On Asset)}

Koefisien regresi DER bernilai negatif sebesar -0,002. Nilai signifikansi menunjukkan 0,015 yang bernilai lebih kecil daripada $\alpha=0,05$ dan $\mathrm{t}$ hitung 2,473 $>\mathrm{t}$ tabel 1,658. Hal ini menunjukkan variabel DER berpengaruh negatif dan signifikan terhadap variabel ROA. Sehingga hipotesis yang menyatakan terdapat pengaruh positif hutang terhadap profitabilitas ditolak.

Hutang pada bank identik dengan sumber dana bank itu sendiri, karena sebagian besar sumber dana bank berasal dari hutang (liabilities) bank terhadap nasabahnya dan merupakan kewajiban yang harus dipenuhi bilamana dana tersebut ditarik atau jatuh tempo. Semakin besar DER, maka semakin besar pula laba yang diterima oleh pihak bank. Hasil perhitungandalam penelitian ini menunjukkan hal yang berbanding terbalik dengan pernyataan tersebut, hasil perhitungan dalam penelitian ini menunjukkan bahwa ketika DER mengalami kenaikan maka ROA akan mengalami penurunan.

Dari data yang diperoleh, DER Bank yang terdaftar di Bursa Efek Indonesia periode 2011-2015 relatif tinggi dengan rata-rata DER Bank yang terdaftar di Bursa Efek Indonesia periode 2011-2015 sebesar 794,79\%; jauh melampaui batas maksimum yaitu 300\%, kemudian berdasarkan data laporan perhitungan rasio keuangan Bank yang terdaftar di BEI periode 2011-2015, terdapat banyak sekali peningkatan rasio DER yang seharusnya diikuti dengan meningkatnya rasio ROA tetapi malahjustru rasio ROA mengalami penurunan, juga terdapat penurunan rasio DER yang seharusnya diikuti dengan menurunnya rasio ROA tetapi malah justru rasio ROA mengalami peningkatan. Hal ini terjadi karena bank tidak mampu memanfaatkan hutang dengan baik, dimana bank tidak mampu meningkatkan laba ketika hutang dijadikan aktiva produktif, dimana tingkat hutang relatif tinggi tetapi dalam penyaluran dana ke masyarakat masih rendah. Hal tersebut menyebabkan DER berpengaruh negatif dan signifikan terhadap profitabilitas.

\section{d. Pengaruh Pendapatan Bunga (Net Interest Margin) terhadap Profitabilitas (Return On Asset)}

Koefisien regresi variabel NIM bernilai positif sebesar 0,335. Nilai signifikansi menunjukkan bahwa 0,000 yang nilainya lebih kecil dari pada $\alpha=0,05$ dan nilai t hitung $5,917>\mathrm{t}$ tabel 1,658. Hal ini menunjukkan bahwa variabel NIM berpengaruh positif dan sigifikan terhadap ROA. Penelitian ini konsisten dengan penelitian Fitriani (2010) yang menyatakan NIM bepengaruh positif dan signifikan terhadap ROA. Sehingga hipotesis yang menyatakan terdapat pengaruh positif dan signifikan pendapatan bunga terhadap profitabilitas diterima.

Net Interest Margin menunjukkan kemampuan bank dalam menghasilkan pendapatan dari bunga dengan melihat kinerja bank dalam mengolah aktiva produktif. Perubahan suku bunga serta kualitas aktiva produktif pada perusahaan perbankan dapat menambah laba bagi bank. Bank telah melakukan tindakan yang berhati-hati dalam memberikan kredit sehingga kualitas aktiva produktifnya tetap terjaga, selain itu untuk dapat meningkatkan perolehan NIM perlu menekan biaya dana, biaya dana adalah bunga yang dibayarkan oleh bank kepada masing-masing sumber dana bank yang bersangkutan. Secara keseluruhan, biaya yang harus dikeluarkan oleh bank akan menentukan berapa persen bank akan menetapkan tingkat bunga kredit yang diberikan kepada nasabahnya untuk mendapatkan pendapatan bersih bank dari bunga. Hasil perhitungan dalam penelitian ini menunjukkan hal yang sejalan dengan pernyataan tersebut. Dari data yang diperoleh, NIM Bank yang terdaftar di Bursa Efek 
Indonesia periode 2011-2015 dengan rata-rata NIM sebesar 5,52\%, masih dibawah batas minimumyaitu $6 \%$.

\section{e. Pengaruh Secara Simultan}

Penelitian ini bertujuan untuk mengetahui pengaruh resiko kredit, kecukupan modal, hutang, dan pendapatan bunga secara simultan terhadap profitabilitas. Berdasarkan hasil analisis di atas nilai signifikansi sebesar 0,000 yaitu lebih kecil dari 0,05 dan f hitung 19,805 > f tabel 2,450 sehingga hipotesis yang menyatakan terdapat pengaruh resiko kredit, kecukupan modal, hutang, dan pendapatan bunga secara simultan terhadap profitabilitas diterima.

\section{KESIMPULAN DAN SARAN \\ 1. Kesimpulan}

a. Secara parsial terdapat pengaruh negatif dan signifikan Resiko Kredit terhadap Profitabilitas, hal ini dibuktikan dengan nilai $\mathrm{B}$ bernilai negatif sebesar $-0,336$ dan nilai $\mathrm{t}$ hitung 4,223 > t tabel 1,658 dan nilai signifikansi sebesar 0,000 $<0,05$.

b. Secara parsial tidak terdapat pengaruh Kecukupan Modal terhadap Profitabilitas, hal ini dibuktikan dengan nilai $\mathrm{B}$ bernilai negatif $-0,020$ dan nilai $\mathrm{t}$ hitung 1,431< $\mathrm{t}$ tabel 1,658 dan nilai signifikansi sebesar $0,155>0,05$.

c. Secara parsial terdapat pengaruh negatif dan signifikan Hutang terhadap Profitabilitas, hal ini dibuktikan dengan nilai $\mathrm{B}$ bernilai negatif sebesar $-0,002$ dan nilai $\mathrm{t}$ hitung 2,473>t tabel 1,658 dan nilai signifikansi sebesar $0,015<0,05$.

d. Secara parsial terdapat pengaruh positif dan signifikan Pendapatan Bunga terhadap Profitabilitas, hal ini dibuktikan dengan nilai $\mathrm{B}$ bernililai positif sebesar 0,335 dan nilai $\mathrm{t}$ hitung 5,917 > t tabel 1,658 dan nilai signifikansi sebesar 0,000 $<0,05$.

e. Secara simultan terdapat pengaruh Resiko Kredit, Kecukupan Modal, Hutang, dan Pendapatan Bunga terhadap Profitabilitas. Nilai signifikansi sebesar 0,000. $<0,050$ dan $\mathrm{f}$ hitung 19,805 > f tabel 2,450.

\section{Saran}

Perbankan sebaiknya mempertimbangkan faktor - faktor Resiko Kredit, Kecukupan Modal, Hutang, dan Pendapatan Bunga dalam konteks pencapaian tingkat laba yang diharapkan dengan memperhatikan kualitas penyaluran kredit, mengolah modal dengan baik dan menggunakan modalnya secara efektif, tingkat hutang dimana hutang yang dijadikan aktiva produktif harus dimanfaatkan dengan baik sehingga menghasilkan laba tinggi, dan menjaga tingkat suku bunga kredit yang ditawarkan.

\section{DAFTAR PUSTAKA}

BI. 2015. Tentang Kewajiban Penyediaan Modal Minimum Bank, www.bi.go.id.

BI. 2015. Tentang Resiko Kredit, www.bi.go.id.

Darma. G. 2012. ANALISIS PENGARUH JUMLAH AKTIVA PRODUKTIF BANK TERHADAP TINGKAT RENTABILITAS.

http://banking.blog.gunadarma.ac.id/2012/04/13/analisis pengaruh-jumlah-aktivaproduktif-bank-terhadap-tingkat rentabilitas/. diakses 6 april 2017.

Debt To Equity Ratio (DER). https://www.seventhsoft.net/artikel/debt-to-equity-ratio-der, diakses 6 april 2017.

Ghozali, I. 2006. Aplikasi Analisis Multivariate Dengan Program SPSS. Semarang: Badan Penerbit Universitas Dipenogoro. 
Hidayat.T.2011.Cara Menganalisis Debt to Equity Ratio. (Online). http://www.teguhhidayat.com/2011/07/tips-menganalisis-debt-to-equity-ratio.html, diakses 6 april 2017.

Kasmir. 2012. Analisis Laporan Keuangan. Jakarta: PT RajaGrafindo Persada.

Kasmir. 2008. Bank dan Lembaga Keuangan Lainnya. Jakarta: PT RajaGrafindo Persada.

Kieso. E. Donald, dkk. 2008. Akuntansi Intermedite. Jakarta: Erlangga.

Mardiasmo. 1993. Akuntansi Keuangan Dasar 1. Yogyakarta: BPFE- Yogyakarta.

Novianty D Bella. 2016. Pengaruh Resiko Kredit, Perputaran Kas, dan Tingkat Kecukupan Modal Terhadap Profitabilitas Perusahaan Perbankan yang Terdaftarr di BEI periode 2012-2014. Lampung: Program Sarjana Universitas Lampung.

Pandia, F. 2012. Manajemen Dana dan Kesehatan Bank. Jakarta: Rineka Cipta.

Putri, S Fifit. 2013. Pengaruh Resiko Kredit dan Kecukupan Modal Terhadap Tingkat Profitabilitas Pada Perusahaan perbankan yang Terdaftar di BEI. Jurnal:(2-10).

Rimsky, K Judisseno. 2002. Sistem Moneter dan Perbankan di Indonesia. Jakarta: PT Gramedia Pustaka Utama.

Surat Edaran Bank Indonesia Nomor 3/30/DPNP tanggal 14 Desember 2001 tentang pedoman perhitungan rasio keuangan.

SURAT KEPUTUSAN DIREKSI BANK INDONESIA No. 31 / 147 / KEP / DIR TENTANG KUALITAS AKTIVA PRODUKTIF.

Surat edaran No.6/ 23 /DPNP tentang Sistem Penilaian Tingkat Kesehatan Bank Umum. 2004. Jakarta.

Undang-Undang No. 10 Tahun 1988 Tentang Perbankan.

Utami. M. Sari. Analisis LDR dan NIM terhadap Laba perbankan yang Terdaftar di BEI Periode 2007-2012. Universitas Komputer Indonesia

Wirartha, I Made. 2005. Metodologi Penelitian Sosial Ekonomi. Yogyakarta: Penerbit Andi. 